\title{
PENGHILANGAN HEMISELULOSA SERAT BAMBU SECARA ENZIMATIK UNTUK PEMBUATAN SERAT BAMBU
}

\section{ENZYMATIC HEMICELLULOSE REMOVAL OF BAMBOO FIBRE FORTHE BAMBOO FIBRE MANUFACTURING}

\author{
Ono Suparno*)dan Roberto Danieli \\ Departemen Teknologi Industri Pertanian, Fakultas Teknologi Pertanian, Institut Pertanian Bogor \\ Kampus IPB Darmaga, Bogor 16680, Indonesia \\ E-mail: ono.suparno@ipb.ac.id \\ Makalah: Diterima 12 April 2016; Diperbaiki 20 Februari 2017; Disetujui 1 Maret 2017
}

\begin{abstract}
Hemicellulose and lignin removal process or degumming of bamboo fibre using cellulase and xylanase was conducted. The objectives of the study were to obtain suitable type of bamboo used in the enzymatic degumming process and to determine the optimum xylanase concentration for the hemicellulose hydrolysis of the selected bamboo. The types of bamboos used in this study were yellow bamboo,ropebamboo, and black bamboo. The study was conducted by enzymatic hydrolyses of the bamboo fibres, and measuring the yield, cellulose content, hemicellulose content, and reducing sugar content. Fibre hydrolysis used the cellulase concentration of $25 \mathrm{U} / \mathrm{g}$ and xylanase concentrationsof 50 to $500 \mathrm{U} / \mathrm{g}$. The result showed that yellow bamboo contained cellulose and hemicellulose contents which most susceptible to hydrolysis resulting in reducing sugars, and decreasing cellulose and hemicellule contents of $6.40 \%$ and $12.71 \%$, respectively. The optimum xilanase concentration for the yellow bamboohydolysis was $400 \mathrm{U} / \mathrm{g}$ which could hydrolyze hemicellulose by $54.31 \%$ in 24 hours.
\end{abstract}

Keywords: bamboo fibre, cellulase, xylanase, hydrolysis, enzymatic process

\begin{abstract}
ABSTRAK
Proses penghilangan hemiselulosa dan lignin dari serat bambu atau degumming dengan menggunakan selulase dan xilanase dilakukan. Penelitian ini bertujuan untuk mendapatkan jenis bambu yang sesuai dalam proses degumming serat bambu didasarkan atas mutu dan untuk menentukan konsentrasi enzim xilanase terbaik untuk hidrolisis hemiselulosa serat bambu terpilih. Bambu yang digunakan adalah bambu kuning, bambu tali, dan bambu hitam. Penelitian dilakukan dengan menghidrolisis serat bambu secara enzimatik dan mengukur rendemen, kadar selulosa, kadar hemiselulosa, dan kadar gula pereduksi. Hidrolisis serat bambu menggunakan konsentrasi selulase $25 \mathrm{U} / \mathrm{g}$ dan xilanase 50 sampai dengan $500 \mathrm{U} / \mathrm{g}$. Hasil penelitian ini menunjukkan bahwa bambu kuning mempunyai kandungan selulosa dan hemiselulosa yang paling mudah terhidrolisis menghasilkan gula pereduksi tertinggi dengan penurunan kadar selulosa sebesar 6,40\% dan dengan penurunan hemiselulosa sebesar $12,71 \%$. Konsentrasi xilanase terbaik untuk menghidrolisis bambu kuning adalah sebesar $400 \mathrm{U} / \mathrm{g}$ yang dapat menghidrolisis hemiselulosa sebesar 54,31\% selama 24 jam.
\end{abstract}

Kata kunci: serat bambu, selulosa, xilanase, hidrolisis, proses enzimatik

\section{PENDAHULUAN}

Indonesia merupakan salah satu negara yang kaya dengan keanekaragaman hayatinya. Salah satu tumbuhan yang tumbuh baik dalam kondisi iklim Indonesia adalah bambu. Bambu sebagai bahan baku industri tekstil yang eco-friendly memiliki beberapa keunggulan, yakni sangat cepat tumbuh dan mengandung senyawa anti-mikrobial. Serat bambu merupakan bahan yang digunakan sebagai bahan baku industri tekstil (Rathod dan Kolhatkar, 2012). Kain yang terbuat dari serat bambu memiliki keuntungan, yaitu $100 \%$ mudah terdegradasi oleh mikroorganisme, serta proses dekomposisi kain bambu tidak berbahaya karena tidak menggunakan bahan kimia. Kain bambu juga memiliki kelebihan, yaitu hangat saat musim dingin, namun sejuk saat musim panas. Hal ini karena kemampuan breathable lebih baik dibandingkan dengan kain biasa (Marilyn, 2009).

Bambu memiliki komponen lignoselulosa berupa lignin, selulosa, dan hemiselulosa. Selulosa merupakan bahan yang akan digunakan untuk pembuatan serat bambu, sehingga perlu adanya proses pemisahan lignin dan hemiselulosa untuk mendapatkan selulosa. Delignifikasi merupakan proses penghilangan lignin pada bahan lignoselulosa.Serat bambu dapat diperoleh dengan cara biologis, mekanis, maupun kimiawi. Proses pemisahan serat bambu secara biologis adalah dengan cara menghancurkan bambu lalu dilanjutkan dengan penambahan enzim alami. Proses mekanis dilakukan dengan cara menghancurkan bambu dan penambahan enzim, sedangkan proses kimia salah satunya dilakukan dengan penambahan bahan kimia $\mathrm{NaOH}$ dan $\mathrm{CS}_{2}$ (carbon disulfide) (Devi et al.,

*Penulis untuk korespondensi 
2007). Penggunaan bahan-bahan kimia akan berdampak buruk bagi kesehatan dan serat yang diperoleh tidak boleh digunakan sebagai bahan tekstil seperti pakaian (Jiajia, 2012). Berdasarkan dampak yang ditimbulkan oleh metode kimia, maka metode biologis merupakan pilihan yang paling tepat untuk memperoleh serat bambu.

Beberapa jenis enzim seperti xilanase dan selulase dibutuhkan untuk mendapatkan serat bambu. Penggunaan xilanase bertujuan memisahkan hemiselulosa yang terdapat pada bambu. Penggunaan selulosa merupakan perlakuan untuk mengubah struktur dan permukaan selulosa, sehingga selulase dapat diproses. Selulosa pada umumnya terdiri atas zona kristalin dan amorf dengan jumlah kandungan yang bervariasi berdasarkan sumber bahan (Jiajia, 2012). Sebagian besar bahan-bahan reaktan hanya bekerja pada bagian amorf karena bagian tersebut terdapat pada permukaan dari bagian kristalin, sehingga bagian intracrystalline tidak terpengaruh oleh reaktan (Ciolacu et al., 2011).

Pada proses ekstraksi serat bambu secara enzimatis, proses inkubasi merupakan salah satu proses yang penting karena mempengaruhi energi dan waktu yang diperlukan. Untuk mengatasi permasalahan waktu inkubasi dalam proses pemisahan serat bambu, maka berbagai penelitian untuk mengurangi waktu hidrolisis dilakukan seperti pemberian perlakuan pendahuluan. Selain itu juga dapat dilakukan pemilihan sumber serat bambu yang sesuai. Pada penelitian ini digunakan tiga jenis bambu yang banyak dibudidayakan di Indonesia, yaitu bambu kuning, bambu hitam, dan bambu tali. Jenis bambu dipilih berdasarkan kecepatan hidrolis hemiselulosa secara enzimatik.

Tujuan penelitian ini adalah untuk untuk mendapatkan jenis bambu yang sesuai dalam proses degumming serat bambu didasarkan atas mutu dan untuk menentukan konsentrasi enzim xilanase terbaik untuk hidrolisis hemiselulosa serat bambu terpilih.

\section{METODE PENELITIAN}

\section{Alat dan Bahan}

Bahan baku yang digunakan dalam penelitian ini adalah bambu kuning (Bambusa vulgaris), bambu tali (Gigantochloa apus), dan bambu hitam (Gigantochloa atroviolacea) yang diperoleh dari Desa Sukaresmi, Tamansari, Bogor. Bahan baku tersebut digiling untuk mendapatkan serbuk bambu dengan ukuran lolos pada saringan 30 mesh. Bahan kimia terdiri atas $\mathrm{NaOH}, \mathrm{Na}_{2} \mathrm{SO}_{3}$, bufer sitrat, DNS, $\mathrm{HNO}_{3}, \mathrm{CH}_{3} \mathrm{COOH}, \mathrm{NaHClO}_{2}$, $\mathrm{H}_{2} \mathrm{SO}_{4}$, dan etanol benzena. Enzim yang digunakan adalah xilanase danselulosa yang diperoleh dari CV Endsany, Sukoharjo, Jawa Tengah. Alat-alat utama yang digunakan adalah shaker, otoklaf, hammer mill, oven, blender, penangas air, termometer, $\mathrm{pH}$ meter, dan spektrofotometer.

\section{Metode}

Karakterisasi Sifat Kimia Bambu

Pada percobaan ini bambu diperkecil ukurannya dengan menggunakan hammer mill sampai ukuran yang lolos pada 30 mesh, lalu dicuci dengan air untuk menghilangkan zat-zat pengotor, dan dikeringkan di dalam oven pada suhu $75^{\circ} \mathrm{C}$ selama satu hari. Sifat kimia bamboo yang diukur adalah kadar selulosa, hemiselulosa, lignin, dan zat ekstraktif (TAPPI, 1997). Hemiselulosa ditentukan dari selisih dari holoselulosa dan selulosa yang dianalisis. Pengujian sifat kimia dilakukan untuk mengetahui kondisi bambu sebelum hidrolisis menggunakan enzim serta untuk mengetahui perbedaan karakteristik setiap bambu, yang mungkin berpengaruh terhadap proses hidrolisis.

\section{Karakterisasi Enzim}

Pada penelitian pendahuluan juga dilakukan pengujian aktivitas enzim dan pengujian kondisi optimal enzim. Pengujian aktivitas enzim bertujuan mengetahui aktivitas enzim yang digunakan sehingga dapat ditentukan jumlah enzim yang akan digunakan. Kondisi optimal enzim dilakukan dengan menguji aktivitas enzim pada suhu tertentu dan $\mathrm{pH}$ tertentu. Penentuan $\mathrm{pH}$ optimal untuk xilanase dan selulosa dilakukan pada $\mathrm{pH} 4,5 ; 5,0 ; 5,5$; dan 6,0 pada suhu $45^{\circ} \mathrm{C}$, untuk penentuan suhu optimal untuk xilanase dilakukan pada suhu 40,50 , dan $60^{\circ} \mathrm{C}$ pada $\mathrm{pH} 5,5$, sedangkan untuk enzim selulosa dilakukan pada suhu $37^{\circ} \mathrm{C}$ dan $45^{\circ} \mathrm{C}$.

Bambu yang digunakan dalam bentuk serbuk berukuran lolos 30 mesh. Bahan disterilkan di dalam otoklafdengan suhu $120^{\circ} \mathrm{C}$ selama 15 menit. Kemudian, sebanyak $1 \mathrm{~g}$ serbuk bambu disaring dan siap digunakan sebagai substrat.

\section{Hidrolisis Selulosa}

Satu gram serbuk bambu yang telah disterilkan ditambah dengan $100 \mathrm{~mL}$ buffer sitratfosfat $\mathrm{pH}$ 5,5, kemudian ditambahkan $25 \mathrm{U} / \mathrm{g}$ enzim selulosa. Campuran diinkubasikan pada suhu $37{ }^{\circ} \mathrm{C}$ selama 24 jam, kemudian cairan dipisahkan dan dianalisis kandungan gula pereduksi. Padatan diuji komponen kadar selulosa dan hemiselulosanya.

\section{Hidrolisis Hemiselulosa}

Satu gram serbuk bambu yang telah disterilkan ditambah $100 \mathrm{~mL}$ buffer sitrat-fosfat $\mathrm{pH}$ 5,5, kemudian ditambahkan xilanase $50 \mathrm{U} / \mathrm{g}$. Campuran diinkubasikan pada suhu $50^{\circ} \mathrm{C}$ selama 24 jam, kemudian cairan dipisahkan dan dianalisis kandungan gula pereduksi. Padatan diuji komponen kadar selulosa dan hemiselulosa. 


\section{Penentuan Konsentrasi Enzim pada Hidrolisis} Hemiselulosa

Pada penentuan konsentrasi enzim, bambu yang digunakan hanya satu jenis, yaitu bambu yang paling mudah terhidrolisis menggunakan selulase dan xilanase berdasarkan analisis gula sederhana, kadar selulosa, dan kadar hemiselulosa pada tahap hidrolisis selulosa dan hidrolisis hemiselulosa. Satu gram serbuk bambu yang telah disterilkan ditambah dengan $100 \mathrm{~mL}$ buffer sitrat-fosfat $\mathrm{pH}$ 5,5, kemudian ditambah dengan xilanase dengan konsentrasi 50, 100, 150, 200, 250, 300, 350, 400, 450, dan $500 \mathrm{U} / \mathrm{g}$. Campuran terseut diinkubasikan pada suhu $50^{\circ} \mathrm{C}$ selama 24 jam. Kondisi optimal pada selulosa adalah suhu $37^{\circ} \mathrm{C}$ dan $\mathrm{pH} 5,5$ sedangkan pada xilanase adalah pada suhu $50^{\circ} \mathrm{C}$ dan $\mathrm{pH}$ 5,5. Cairan dipisahkan dan dianalisis kandungan gula pereduksinya. Padatan diuji komponen kadar selulosa dan hemiselulosa.

\section{HASIL DAN PEMBAHASAN}

\section{Karakteristik Bambu}

Karakteristik kimia bambu terdiri atas kadar holoselulosa, selulosa, hemiselulosa, lignin klason, dan zat ekstraktif. Tabel 1 menunjukkan sifat-sifat kimia bambu kuning, bambu hitam, dan bambu tali.

Kadar zat ekstraktif bambu kuning pada pelarut etanol benzena 2:1 adalah sebesar 3,77\%. Jika dibandingkan dengan zat ekstraktif bambu yang biasanya diantara 5-9\% (Fatriasari, 2008), zat ekstraktif bambu kuning yang diperoleh tergolong rendah. Kadar holoselulosa yang diperoleh adalah sebesar 69,57\%. Fatriasari (2008) menyatakan pada umumnya bambu memiliki kadar holoselulosa antara 70-80\%. Berdasarkan data tersebut bambu kuning yang diamati memiliki kadar holoselulosa yang tidakjauh berbeda. Kadar lignin yang diperoleh tergolong kecil, yaitu sebesar 21,23\% dibandingkan dengan kadar lignin bambu pada umumnya, yaitu 25-30\% (Fatriasari, 2008).

Bambu hitam memiliki kandungan zat ekstraktif lebih tinggi dibandingkan dengan bambu kuning, yaitu 4,12\%. Kandungan holoselulosa yang dimiliki bambu hitam lebih rendah dibandingkan dengan bambu kuning, yaitu 64,43\%. Kandungan hemiselulosa bambu hitam juga lebih kecil dari bambu kuning, yaitu 21,16\%. Bambu hitam memiliki kandungan lignin yang lebih tinggi dibandingkan bambu kuning, yaitu 24,33\%.

Bambu tali memiliki kandungan zat ekstraktif paling tinggi dibandingkan dengan dua jenis bambu lainnya, yaitu $4,45 \%$. Kandungan holoselulosa pada bambu tali merupakan yang paling rendah, yaitu $63,23 \%$, dan hemiselulosa $20,78 \%$. Kandungan lignin bambu tali merupakan yang tertinggi dibandingkan dengan dengan dua jenis bambu lainnya, yaitu 24,87\%.

\section{Karakteristik Enzim}

Aktivitas enzim merupakan kemampuan enzim dalam mendegradasi suatu substrat atau membentuk produk (Suparno, 2005; Suparno et al., 2007). Semakin tinggi akvitas enzim, semakin banyak substrat yang terdegradasi dan semakin banyak produk yang terbentuk oleh enzim tersebut.

Tabel 2 menunjukkan antivitas selulase sebagai CMC-ase pada suhu tertentu. Selulase memiliki konsentrasi enzim sebesar $250 \mathrm{U} / \mathrm{g}$. Hasil tersebut menunjukkan bahwa selulase bekerja dengan optimal pada suhu $37^{\circ} \mathrm{C}$ dan $\mathrm{pH} 5,5$.

Tabel 2. Aktivitas CMC-ase pada suhu $37^{\circ} \mathrm{C}$ dan $\mathrm{pH}$ 5,5

\begin{tabular}{cc}
\hline Suhu $\left({ }^{\circ} \mathbf{C}\right)$ & Aktivitas CMC-ase (U/g) \\
\hline 37 & $250 \pm 12$ \\
45 & $221 \pm 17$ \\
\hline
\end{tabular}

Tabel 3 menunjukkan aktivitas xilanase pada suhu tertentu. Konsentrasi xilanase yag digunakan adalah $550 \mathrm{U} / \mathrm{g}$. Kondisi optimal untuk xilanase adalah pada suhu $50^{\circ} \mathrm{C}$ dan $\mathrm{pH} 5,5$.

Tabel 3. Aktivitas xilanase pada pH 5,5 dan berbagai suhu

\begin{tabular}{cc} 
Suhu $\left({ }^{\mathbf{}} \mathbf{C}\right)$ & Aktivitas xilanase $(\mathbf{U} / \mathbf{g})$ \\
\hline 40 & $437 \pm 21$ \\
50 & $550 \pm 27$ \\
60 & $492 \pm 18$ \\
\hline
\end{tabular}

\section{Hidrolisis Selulosa}

Hidrolisis selulosa menggunakan selulase menghasilkan produk berupa gula pereduksi (glukosa). Gambar 1 menunjukkan perbedaan jumlah gula pereduksi hasil hidrolisis menggunakan selulase. Berdasarkan data tersebut dapat diketahui bahwa bambu kuning lebih mudah terhidrolisis dengan menggunakan selulase dibandingkan dengan bambu hitam dan bambu tali. Hidrolisis bambu kuning menghasilkan gula pereduksi rata-rata sebesar 393 ppm, sedangkan untuk bambu hitam dan bambu tali tidak memiliki perbedaan yang terlalu jauh, yakni dimana bambu hitam menghasilkan gula pereduksi sebesar 266 ppm dan bambu tali sebesar $275 \mathrm{ppm}$.

Tabel 1. Sifat-sifat kimia bambu kuning, bambu hitam, dan bamboo tali

\begin{tabular}{lccc}
\hline Sifat Kimia & Bambu Kuning & Bambu Hitam & Bambu Tali \\
\hline Zat ekstraktif (\%) & $3,77 \pm 0,02$ & $4,12 \pm 0,01$ & $4,45 \pm 0,01$ \\
Kadar holoselulosa (\%) & $69,57 \pm 0,07$ & $64,43 \pm 0,08$ & $63,23 \pm 0,07$ \\
Kadar selulosa (\%) & $47,33 \pm 0,11$ & $43,27 \pm 0,09$ & $42,45 \pm 0,05$ \\
Kadar hemiselulosa (\%) & $22,24 \pm 0,08$ & $21,16 \pm 0,03$ & $20,78 \pm 0,03$ \\
Kadar lignin Klason(\%) & $21,23 \pm 0,04$ & $24,33 \pm 0,07$ & $24,87 \pm 0,06$ \\
\hline
\end{tabular}


Proses hidrolisis enzimatik dipengaruhi oleh beberapa faktor, yaitu enzim, ukuran partikel, suhu, pH, waktu hidrolisis, perbandingan cairan terhadap bahan baku (volume substrat), dan pengadukan. Selain itu, hidrolisis juga dipengaruhi oleh karakteristik substrat dan kandungan pada substrat tersebut (Purba, 2009). Proses hidrolisisdipengaruhi oleh kadar lignin dalam serat. Ikatan silang dari struktur aromatik lignin dapat memperlambat penetrasi enzim, sehingga mempengaruhi proses hidrolisis (Safaria et al., 2013). Perbedaan hasil hidrolisis pada bambubambu tersebut disebabkan oleh kandungan lignin. Kandungan lignin pada bambu hitam dan bambu tali cukup tinggi dibandingkan dengan kandungan lignin bambu kuning, sehingga selulase lebih sulit menghidrolisis selulosa.

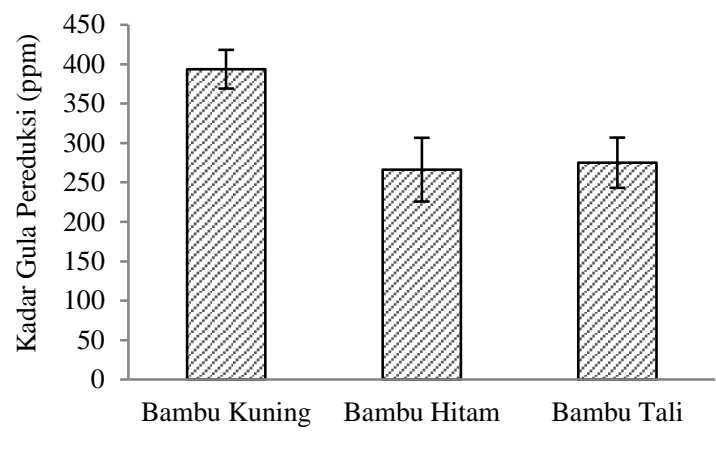

Jenis Bambu

Gambar 1. Kadar gula pereduksi yang terbentuk dari bambu setelah hidrolisis menggunakan selulase

Perlakuan enzim dapat mengakibatkan perubahan struktur dan permukaan dari serat (Jiajia, 2012). Selulase mengubah permukaan serat menjadi lebih lembut dan lebih lentur, sehingga daya putus serat dan daya pintal menjadi lebih baik. Hidrolisis selulosa menggunakan selulase mengakibatkan penurunan jumlah selulosa yang terkandung pada bambu sebagaimana ditunjukkan pada Tabel 4. Penurunan selulosa pada bambu kuning lebih tinggi dibandingkan dengan bambu hitam maupun bambu tali, sedangkanpenurunan selulosa pada bambu kuning lebih besar dibandingkan dengan penurunan pada bambu hitam dan bambu tali (Gambar 2).

Tabel 4. Rendemen, kadar selulosa bambu sebelum dan setelah hidrolisis menggunakan selulase

\begin{tabular}{lccc}
\hline $\begin{array}{c}\text { Jenis } \\
\text { bambu }\end{array}$ & $\begin{array}{c}\text { Rendemen } \\
(\%)\end{array}$ & $\begin{array}{c}\text { Selulosa } \\
\text { awal (\%) }\end{array}$ & $\begin{array}{c}\text { Selulosa } \\
\text { akhir (\%) }\end{array}$ \\
\hline $\begin{array}{l}\text { Bambu } \\
\text { kuning }\end{array}$ & $96,23 \pm 0,05$ & $47,33 \pm 0,11$ & $46,03 \pm 0,01$ \\
$\begin{array}{l}\text { Bambu } \\
\text { hitam }\end{array}$ & $95,88 \pm 0,12$ & $43,27 \pm 0,09$ & $42,62 \pm 0,07$ \\
$\begin{array}{l}\text { Bambu } \\
\text { tali }\end{array}$ & $95,55 \pm 0,08$ & $42,45 \pm 0,05$ & $43,, 95 \pm 0,05$ \\
\hline
\end{tabular}

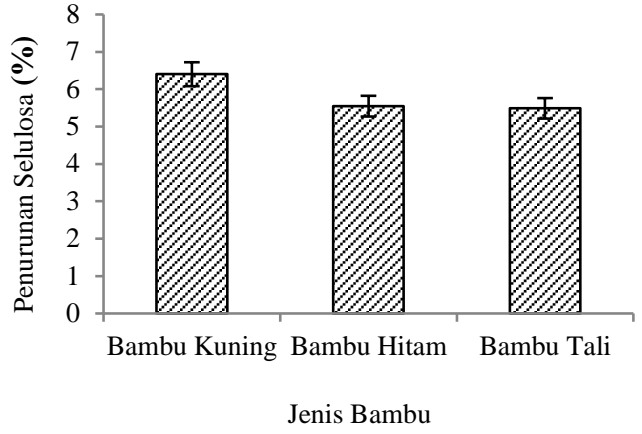

Gambar 2. Penurunan selulosa pada bambu setelah hidrolisis dengan enzim selulosa

Penurunan jumlah selulosa pada bambu berbanding lurus dengan jumlah gula pereduksi yang dihasilkan dari hidrolisis selulosa dengan selulase. Semakin besar jumlah selulosa pada bamboo yang dihidrolisis, semakin tinggi gula pereduksi yang dihasilkan. Penurunan selulosa pada bambu kuning lebih tinggi dibandingkan dengan bambu yang lain.

\section{Hidrolisis Hemiselulosa}

Hidrolisis hemiselulosa (xilan) dan lignin pada serat bambu akan meningkatkan kemurnian serat selulosa yang dihasilkan, sehingga karakteristik serat dan kain yang dihasilkan akan semakin baik, yakni lebih lembut dan lentur, daya putus serat dan daya pintal menjadi lebih baik. Hidrolisis hemiselulosa menggunakan xilanase menghasilkan produk xilosa yang merupakan salah satu gula pereduksi.

Gambar 3 menunjukkan perbedaan jumlah gula pereduksi hasil hidrolisis menggunakan xilanase. Hemiselulosa bambu kuning juga lebih mudah terhidrolisis dibandingkan dengan hemiselulosa bambu hitam dan bamboo tali. Gula pereduksi yang dihasilkan dari hidrolisis bambu kuning lebih tinggi dibandingkan dengan gula pereduksi dari hidrolisis bambu hitam dan dan bambu tali. Seperti halnya hidrolisis selulosa, hidrolisis xilan juga dipengaruhi oleh kandungan lignin dalam bambu yang dapat menghambat penetrasi xilanase. Oleh karena itu, bambu kuning dengan kandungan lignin terendah dapat terhidrolisis dengan mudah dengan xilanase

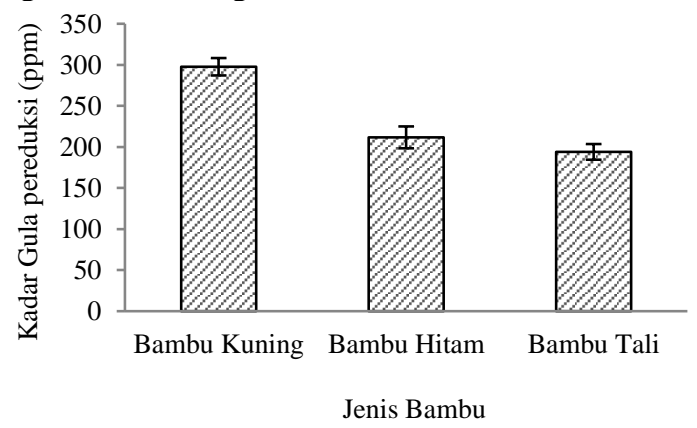

Gambar 3. Gula pereduksi yang terbentuk setelah hidrolisis bambu menggunakan xilanase 
Xilan lebih sulit terhidrolisis dibandingkan dengan selulosa karena jumlah kandungan xilan yang kecil. Xilan pada permukaan kembali mengendap sehingga sebagian xilan yang terletak lebih jauh di dalam tidak terjangkau oleh enzim (Wedin et al., 2007). Hidrolisis hemiselulosa menggunakan xilanase mengakibatkan penurunan pada jumlah hemiselulosa yang terkandung pada bambu yang dapat dilihat pada Tabel 5. Gambar 4 menunjukkan penurunan kadar hemiselulosa setelah hidrolisis dengan menggunakan xilanase. Penurunan kandungan hemiselulosa pada bambu tidak berbeda dibandingkan dengan data hasil hidrolisis hemiselulosa. Bambu kuning mengalami penurunan kadar hemiselulosa yang paling besar dibanding dengan kedua jenis bambu yang lainnya.

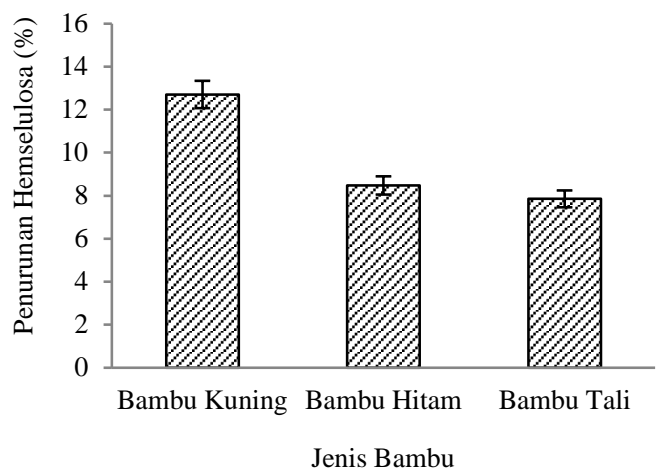

Gambar 4. Penurunan hemiselulosa bambu setelah hidrolisis menggunakan xilanase

Bambu memiliki selulosa, hemiselulosa, dan lignin sebagai bahan penyusun utama. Koomposisi ketiga bahan tersebut lebih dari $90 \%$ dari kandungan kimia yang terdapat pada bambu. Lignin dan hemiselulosa adalah kandungan utama yang ingin dipisahkan melalui proses degumming. Bambu memiliki kandungan hemiselulosa rata-rata 20\%-30\%. Hemiselulosa pada bambu pada sebagian besar mengandung $\beta$-D-xilan, sehingga penggunaan xilanase merupakan metode yang paling tepat dalam proses degumming (Aoyama, 1999).

Penurunan jumlah hemiselulosa pada bambu berbanding terbalik dengan jumlah gula pereduksi yang dihasilkan dari hidrolisis hemiselulosa dengan xilanase. Semakin tinggi gula pereduksi yang dihasilkan maka semakin menurun jumlah hemiselulosa pada bambu. Penurunan hemiselulosa pada bambu kuning lebih tinggi dibandingkan dengan kedua jenis bambu yang lain. Hal tersebut terjadi karena hemiselulosa bambu kuning yang terhidrolisis oleh xilanase lebih banyak dibandingkan dengan kedua jenis bambu lainnya.

Bambu kuning merupakan jenis bambu yang paling cocok untuk pembuatan serat kain bambu dengan menggunakan metode mekanis, karena bambu kuning memiliki kandungan selulosa dan hemiselulosa yang mudah terhidrolisis dengan menggunakan enzim komersial dibandingkan dengan bambu hitam maupun bambu kuning. Dengan menggunakan bambu kuning sebagai bahan dalam pembuatan serat, proses degumming akan lebih cepat dibandingkan dengan jenis bambu yang lain, sehingga serat yang dihasilkan dapat diperoleh lebih cepat, penggunaan enzim dan biaya energi inkubasi dapat diturunkan.

\section{Penentuan Konsentrasi Xilanase}

Pada pembuatan serat kain bambu secara mekanis, hemiselulosa merupakan salah satu komponen kimia yang perlu dihilangkan. Oleh karena itu, pada penelitian ini dilakukan penentuan konsentrasi xilanase terbaik untuk memisahkan hemiselulosa dari bambu.Pada uji ini, selulase tidak digunakan karena dapat merusak selulosa yang ingin diperoleh. Jenis bambu yang digunakan adalah bambu kuning, karena berdasarkan hidrolisis selulosa dan hemiselulosa, bambu kuning merupakan jenis bambu yang paling mudah terhidrolisis menggunakan selulase maupun xilanase. Xilanase menurunkan kadarselulosa dan hemiselulosa pada bambu sebagaimana terlihat pada Tabel 6. Gambar 5 menunjukkan pengaruh konsentrasi xilanase terhadap gula pereduksi yang dihasilkan.

Gambar 5 memperlihatkan peningkatan kadar gula pereduksi yang terbentuk meningkat sampai konsentrasi enzim $350 \mathrm{U} / \mathrm{g}$, sedangkan pada selang konsentrasi $350-500 \mathrm{U} / \mathrm{g}$, gula pereduksi tidak terlihat meningkat secara signifikan. Hal ini dapat disebabkan kandungan hemiselulosa pada bambu sedikit, sehingga gula pereduksi yang dihasilkan juga semakin kecil. Hal ini juga dapat disebabkan enzim tidak dapat menjangkau sisa hemiselulosa sehingga hemiselulosa sulit terhidrolisis (Wedin et al. 2007). Gambar tersebut juga menunjukkan jumlah hemiselulosa yang terhidrolisis setelah penggunaan xilanase. Perubahan hemiselulosa meningkat secara signifikan dari konsentrasi 50 - $350 \mathrm{U} / \mathrm{g}$, pada konsentrasi 350- 500 $\mathrm{U} / \mathrm{g}$, peningkatan cenderung berkurang. Hasil tersebut menunjukkan penurunan hemiselulosa berbanding lurus dengan peningkatan gula pereduksi yang terbentuk.

Tabel 5. Rendemen, komposisi bambu sebelum dan setelah hidrolisis menggunakan xilanase

\begin{tabular}{lcccc}
\hline Jenis bambu & Rendemen (\%) & $\begin{array}{c}\text { Hemiselulosa } \\
\text { awal }(\boldsymbol{\%})\end{array}$ & $\begin{array}{c}\text { Hemiselulosa akhir } \\
(\boldsymbol{\%})\end{array}$ & $\begin{array}{c}\text { Selulosa akhir } \\
(\boldsymbol{\%})\end{array}$ \\
\hline Bambu kuning & $95,29 \pm 0,10$ & $22,24 \pm 0,08$ & $21,21 \pm 0,04$ & $48,63 \pm 0,01$ \\
Bambu hitam & $97,01 \pm 0,19$ & $21,16 \pm 0,03$ & $20,84 \pm 0,08$ & $45,29 \pm 0,01$ \\
Bambu tali & $97,28 \pm 0,19$ & $20,78 \pm 0,03$ & $20,62 \pm 0,08$ & $44,56 \pm 0,01$ \\
\hline
\end{tabular}


Tabel 6. Komposisi bambu kuning setelah hidrolisis menggunakan xilanase

\begin{tabular}{ccccc}
\hline $\begin{array}{c}\text { Konsentrasi } \\
(\mathbf{U} / \mathbf{g})\end{array}$ & $\begin{array}{c}\text { Hemiselulosa } \\
(\boldsymbol{\%})\end{array}$ & $\begin{array}{c}\text { Selulosa } \\
(\boldsymbol{\%})\end{array}$ & $\begin{array}{c}\text { Penurunan } \\
\text { hemiselulosa }(\boldsymbol{\%})\end{array}$ & $\begin{array}{c}\text { Penurunan selulosa } \\
(\boldsymbol{\%})\end{array}$ \\
\hline$($ Awal $)$ & $22,24 \pm 0,08$ & $47,33 \pm 0,11$ & - & - \\
50 & $20,61 \pm 0,02$ & $49,81 \pm 0,01$ & $16,48 \pm 0,16$ & $5,16 \pm 0,05$ \\
100 & $19,78 \pm 0,07$ & $50,01 \pm 0,02$ & $21,50 \pm 0,43$ & $6,74 \pm 0,14$ \\
150 & $18,41 \pm 0,06$ & $50,35 \pm 0,02$ & $29,33 \pm 0,38$ & $9,19 \pm 0,12$ \\
200 & $17,06 \pm 0,04$ & $50,69 \pm 0,01$ & $36,61 \pm 0,25$ & $11,47 \pm 0,08$ \\
250 & $16,05 \pm 0,08$ & $50,94 \pm 0,02$ & $41,74 \pm 0,40$ & $13,07 \pm 0,13$ \\
300 & $14,94 \pm 0,12$ & $51,22 \pm 0,02$ & $47,08 \pm 0,60$ & $14,75 \pm 0,19$ \\
350 & $13,92 \pm 0,10$ & $51,47 \pm 0,03$ & $51,77 \pm 0,46$ & $16,22 \pm 0,14$ \\
400 & $13,50 \pm 0,08$ & $51,58 \pm 0,02$ & $53,66 \pm 0,38$ & $16,81 \pm 0,12$ \\
450 & $13,41 \pm 0,05$ & $51,60 \pm 0,01$ & $54,04 \pm 0,22$ & $16,93 \pm 0,07$ \\
500 & $13,35 \pm 0,08$ & $51,61 \pm 0,02$ & $54,31 \pm 0,36$ & $17,01 \pm 0,11$ \\
\hline
\end{tabular}

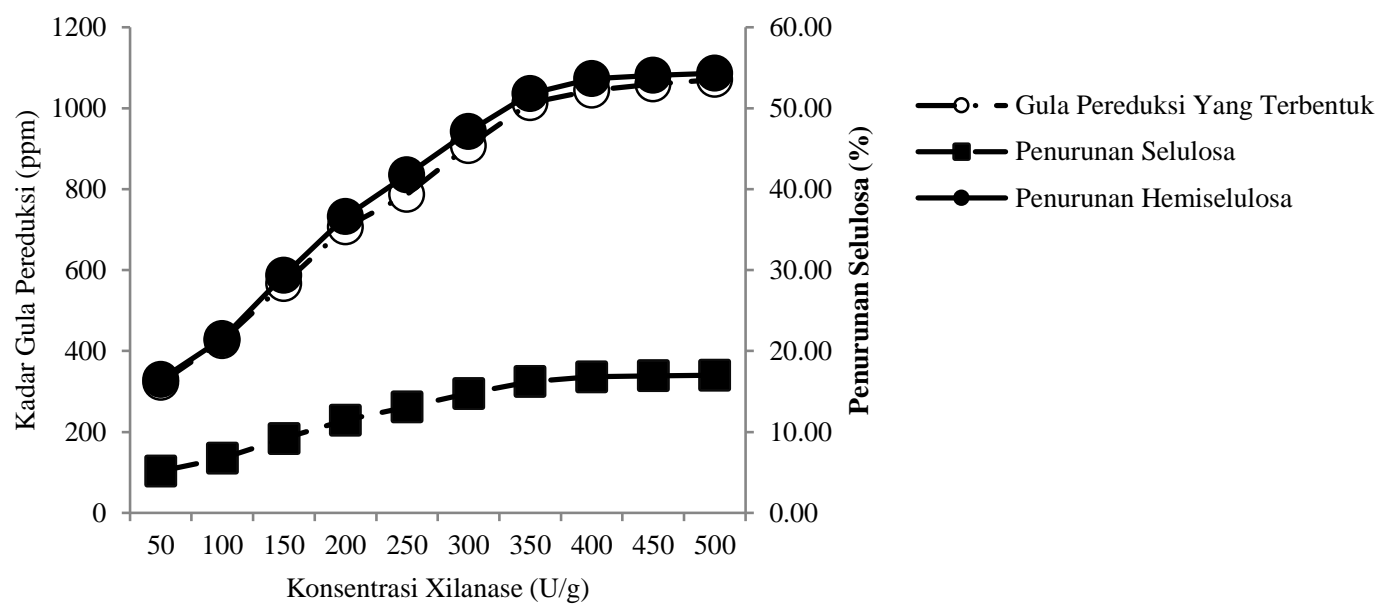

Gambar 5. Pengaruh konsentrasi enzim terhadap kadar gula pereduksi terbentuk, kadar hemiselulosa dan selulosa

Hemiselulosa merupakan bahan yang ingin dihilangkan sebanyak mungkin dari serat agar dapat diperoleh serat dengan kandungan selulosa yang lebih murni. Kadar hemiselulosa pada bambu kuning adalah sekitar 22,24\%, sehingga jumlah hemiselulosa yang ingin dipisahkan adalah $22,24 \%$ dari bobot keseluruhan bambu atau $100 \%$ dari kadar hemiselulosa. Namun, enzim tidak dapat menghilangkan seluruh hemiselulosa meskipun dilakukan penambahan konsentrasi. Hal ini dapat dilihat pada kurva, enzim hanya dapat menghidrolisis hemiselulosa sebesar 54\%, penambahan enzim yang berlebihan dapat memengaruhi biaya proses degumming sehingga dapat disimpulkan penggunaan xilanase yang paling optimal adalah dengan konsentrasi $400 \mathrm{U} / \mathrm{g}$ dengan waktu hidrolisis selama 24 jam. Seiring penambahan konsentrasi xilanase, kemurnian selulosa meningkat karena kadar hemiselulosa pada serat bambu tersebut menurun.

\section{KESIMPULAN DAN SARAN}

\section{Kesimpulan}

Bambu kuning, bambu hitam, dan bambu tali dapat dihidrolisis menggunakan selulase dan xilanase, yang ditunjukkan dengan terbentuknya gula-gula sederhana.Bambu kuning merupakan jenis bambu yang paling cocok digunakan untuk pembuatan serat bambu dibandingkan dengan bambu hitam dan bamboo tali. Bambu kuning memiliki selulosa dan hemiselulosa yang paling mudah terhidrolisis secara enzimatik dibandingkan dengan bambu hitam dan bambu tali. Konsentrasi xilanase terbaik untuk menghidrolisis hemiselulosa pada bambu kuning adalah $400 \mathrm{U} / \mathrm{g}$ yang dapat menurunkan kadar hemiselulosa bambu kuning sebesar 54\% dalam waktu 24 jam.

\section{Saran}

Pengujian mutu serat dari bambu kuning yang dihasilkan perlu dilakukan. Serat bambu kuning yang dihasilkan perlu dicoba untuk dipintal mejadi benang serat bambu, yang kemudian untuk membuat kain.

\section{DAFTAR PUSTAKA}

Aoyama M. 1999. Acid catalysed steaming for solubilization of bamboo grass xylan. Biores Technol. 69:91-94. 
Ciolacu D, Ciolacu F, dan Popa VI. 2011. Amorphous cellulose: structure and characterization. Cellulose Chem Technol. 45(1-2): 13-21.

Devi R, Poornima N, dan Guptan S. 2007. Bamboo: the natural, green and eco-friendly newtype textile material of the 21 st century. $J$. Textile Assoc. 1: 222-224.

Fatriasari W. 2008. Analisis morfologi serat dan sifat fisis-kimia pada enam jenis bambu sebagai bahan baku pulp dan kertas. ITHH 1(2): 67-72.

Jiajia F. 2012. Bamboo fibre processing: insights into hemicellulase and cellulase substrate accessibility. Biocatal Biotrans. 30(1): 2737.

Marliyn W. 2009. Sustainable textiles: the role of bamboo and a comparison of bamboo textile properties. J Text App Technol Mgmt. 6(2): 1-21.

Purba E. 2009. Hidrolisis pati ubi kayu (Manihot esculenta) dan pati ubi jalar (Ipomea batatas) menjadi glukosa secara cold process dengan acid fungal amilase dan glukoamilase. J Tek Ind Pert. 12 (2): 76-81.
Rathod A dan Kolhatkar A. 2012. Handle properties of bamboo and cotton fabric. Di dalam: China Textile Science, Vol. 2, Textech Publishing, 36-40.

Safaria S, Idiawati N, dan Anita T. 2013. Efektivitas campuran enzim selulosa dari Aspergillus niger dan Trichoderma reesei dalam menghidrolisis substrat sabut kelapa. JKK 2(1): 46-51.

Suparno O. 2005. Phenolic reactions for leather tanning and dyeing. [PhD Thesis]. Leicester (UK): University of Leicester.

Suparno O, Covington AD, dan Evans CS. 2007. Application of diphenols for dyeing. $J$ Society Leather Technolog Chem. 91(4): 139-141.

TAPPI. 1997. TAPPI Test Methods. Atlanta (US): TAPPI Press.

Wedin H, Ragnar M, dan Lindstrom ME. 2007. On the role of xylan in oxygen delignification [Tesis]. Stockholm: Royal Institute of Technology Teknikringen. 